DOI: https://doi.org/10.31933/dijms.v2i2 Received: 15 October 2020, Revised: 25 November 2020, Publish: 20 December 2020

\begin{tabular}{|c|c|c|}
\hline PUNASTER & $\begin{array}{l}\text { DINASTI INTERNATIONAL JOURNAL } \\
\text { OF MANAGEMENT SCIENCE }\end{array}$ & $\begin{array}{r}\text { https://dinastipub.org/DIJMS } \\
\text { editor@dinastipub.org } \\
08117401455 @\end{array}$ \\
\hline
\end{tabular}

\title{
FACTORS AFFECTING ORGANIZATIONAL COMMITMENT (A HUMAN RESOURCE MANAGEMENT LITERATURE STUDY)
}

\author{
Wydyanto Wydyanto ${ }^{1}$, Andri Yandi ${ }^{2}$ \\ ${ }^{1)} \mathrm{Ph} . \mathrm{D}$ Student, Institute of Visual Informatic, University Kebangsaan Malaysia, Selangor, Malaysia, email: \\ p93043@siswa.ukm.edu.my \\ 1) Departement of Computer Science, Universitas Bina Darma, Sumatera Selatan 30264, Indonesia, \\ wydyanto@binadarma.ac.id \\ 2) Faculty of Economic, Universitas Batanghari Jambi, Indonesia, email: andriyandi.ali@gmail.com
}

\begin{abstract}
Previous research or relevant research is very important in a research or scientific article. Previous research or relevant research serves to strengthen the theory and phenomenon of the relationship or influence between variables. This article reviews the factors that influence organizational commitment, namely: Individual Characteristics, Compensation, and Job Satisfaction, A Study of Human Resource Management Literature. The results of this research library are that: 1) individual characteristics have an effect on job satisfaction; 2) compensation affects job satisfaction; 3) individual characteristics affect organizational commitment; 4) compensation affects organizational commitment; and 5) job satisfaction affects organizational commitment.
\end{abstract}

Keywords : Job Characteristics, Compensation, Job Satisfaction, and Organizational Commitment.

\section{INTRODUCTION}

Humans as members of the organization play an important role in achieving organizational goals. The success of an organization cannot be separated from human resources because humans have the ability to contribute their energy and thoughts to do something useful. This situation makes human resources an asset whose productivity must be increased. The reliance of the organization on employees makes the organization necessary to foster confidence in employees to have something in common with the values and goals of the organization. This belief will create a feeling of belonging in the employee which is expected to encourage employees to cooperate with the organization. The relationship between employees and the organization they work for is known as organizational commitment.

Employee commitment is an important thing for a company in creating survival. Employees as members of the organization will find it easier to achieve high work performance if they have positive behavior and attitudes. That is, by realizing that he is not only a member of the organization but also understands the goals and values of the organization, employees will be able to understand the goals and policies of the organization. In the end, employees will be able to do 
and work fully for the success of the organization. The low commitment causes losses not only to the company, but also to individuals leaving the company. The clearest indication of low organizational commitment in practice is the high number of employees who are absent and resign or leave the organization. The desire to resign is certainly not easy to be realized given the various conditions that do not or do not allow employees to move from one company to another. Finally, the form of their inability to leave is manifested by not caring about their work and not feeling responsible for the progress of the company.

Commitment in the organization does not just happen very easily and quickly. But it undergoes a gradual and quite long process. According to Steers in Sopiah (2015) states three factors that affect an employee's commitment, namely: 1) Personal characteristics, workers including their position in the organization, and the different needs and desires of each employee; 2) Job characteristics, such as job identity and opportunities to interact with colleagues; and 3) Work experience, such as the reliability of the organization in the past and the ways other workers express and discuss their feelings about the organization.

Meanwhile, according to Minner in Sopiah (2015) four factors that influence employee commitment include: 1) Personal factors, this includes age, gender, education level, work experience and personality, and so on; 2) Job characteristics, such as occupational environment, challenges at work, role conflicts, level of difficulty at work; 3) Characteristics of the structure, for example the size of the organization, the form of the organization, the presence of a work union, and the level of control exercised over employees; and 4) Work experience, this is very influential on the level of commitment of employees in the organization. Because the level of commitment between employees who have been working for decades will be different from employees who have just worked.

According to Steer and Porter in Sopiah (2015), there are a number of factors that affect employee commitment to the organization, namely: 1) Personal factors include job expectations, psychological contracts, job choice factors, and personal characteristics (personality). For all of these factors will form the initial commitment; 2) Organizational factors, including initial works experience, job scope, supervision, goal consistency organizational. All of these factors create and shape responsibility; and 3) Non-organizational factors, which include the avalibleity of alternative jobs. Factors that do not come from within the organization, for example whether there are other job alternatives. If there is something better then the employee will leave.

Based on the theory above, there are many factors that can affect organizational commitment, but in this study the authors only examine two factors. First, personal factors, implemented in the form of job satisfaction. This is Mathis \& Jackson (2006) which states that people who are relatively satisfied with their work will be more committed to the organization and people who are committed to the organization are more likely to get greater satisfaction.

As for the second factor, namely organizational factors, which are implemented in the form of job characteristics and compensation. This was stated by Elanain in Tamalero, Swasto, and Hamid (2012) which emphasized that to increase employee commitment and to reduce turnover intentions, companies need to pay attention to job characteristics factors. Meanwhile, compensation is presented by Hasibuan (2012) which states that the purpose of providing compensation is a partnership, job satisfaction, effective procurement, motivation, employee stability, discipline, and commitment to work. In addition, the amount of compensation received with work targets and workloads that are completed will further motivate employees to work seriously in achieving organizational goals and objectives (Pratama, E.W., Musadieq, M.A., and Mayowan, Y., 2016). 
Based on the background, problems will be formulated that will be discussed in the literature review article so that it will focus more on literature review and the results and discussion later, namely: 1) Do job characteristics have an influence on job satisfaction ?; 2) Does compensation have an influence on job satisfaction ?; 3) Do job characteristics have an influence on organizational commitment ?; 4) Does compensation have an influence on organizational commitment; and 5) Does job satisfaction have an influence on organizational commitment?

\section{LITERATURE REVIEW Organizational Commitment}

According to Mowday, Porter and Steers in Triatna (2015) define organizational commitment as "the relative strength of an individual's identification with and involvement in a particular organization". This definition shows that organizational commitment has a broader meaning than just passive loyalty, but involves interactive relationships and the desire of employees to make meaningful contributions to the organization. In organizational management, it is necessary to have better relations and the desire of employees, namely mutual love for employees who are willing to work and have high organizational commitment.

According to Kreitner and Kinicki (2014) commitment is an agreement to do something for oneself, other individuals, groups, or organizations. Furthermore, Kreitner and Kinicki (2014) explain that organizational commitment is a reflection of where an employee recognizes the organization and is bound to its goals. This is an important work attitude because committed people are expected to demonstrate their availability to work harder to achieve organizational goals and have a greater desire to stay with a company.

According to Robbin and Judge (2015) defines organizational commitment as a condition in which an employee sides with a particular organization and his goals and desires to maintain membership in that organization. Luthan (2006) defines organizational commitment as an attitude that reflects the extent to which an individual knows and is bound to his organization. A highly committed individual is likely to see himself as a true member of the organization.

The commitment of an employee itself is actually a complex thing and of course it is influenced not only by one factor but influenced by many factors, therefore it is called complex. Several factors affect employee commitment, such as reward and desire to be appreciated, the opportunity to develop and learn and are even influenced by organizational or company tolerance when employees make mistakes (Mahapatro, 2010).

According to Martin and Nicholls in Armstrong (1991) states that there are 3 (three) pillars of the importance of organizational commitment, namely: 1) Creating a sense of belonging to the organization, to identify someone in the organization to believe that there are benefits and benefits of working in the organization, for feel comfortable in it, to support the values, vision and mission of the organization in response; 2) Creating enthusiasm at work, this method can be done by concentrating more on managing intrinsic motivation factors and using various job design methods; and 3) Confidence in management, this method can be done when the organization has actually shown and maintained success.

According to Kreitner and Kinicki (2014), there are three forms of organizational commitment, namely: 1) Continuous commitment, namely commitment related to the dedication of members in carrying out organizational life and producing people who are willing to sacrifice and invest in the organization; 2) cohesion commitment, namely commitment of members to the organization as a result of social relationships with other members in the organization. This occurs because employees believe that the norms adopted by the organization are useful norms; and 3) 
Controlled commitment, namely the commitment of members to organizational norms that provide behavior in the direction they want. Organizational norms are appropriate and are able to contribute to the behavior it wants.

Organizational Commitment have been examined extensively by previous researchers including: (Limakrisna et al., 2016), (Harini et al., 2020), (Prayetno \& Ali, 2017), (Riyanto et al., 2017), and (Masydzulhak et al., 2016).

\section{Job Characteristics}

Job characteristics are the nature of the task which includes responsibilities, types of tasks and the level of satisfaction obtained from the job itself. According to Hackman and Oldham in Robbins and Judge (2015), job characteristics are an attempt to identify the job characteristics of the job, how those characteristics are combined to form different jobs and their relationship with motivation, job satisfaction and employee performance.

Job characteristics are attributes of employee duties and include a number of responsibilities, various tasks, and the extent to which the job has characteristics that can make employees feel satisfied (Stoner and Wankel in Tamalero, Y., Swasto, B., and Hamid, D., 2012) . Panggabean (2011) states that job characteristics are related to the job itself, it is related to how employees assess the tasks that are in their work. Pragmatically, answers to questions about job characteristics can be used through job characteristics models.

According to Berry and Houtson in Mangkuprawira (2013) job characteristics are the attitude of the internal aspects of the work itself which consists of the variety of skills required, procedures and clarity of tasks, level of task importance, responsibility and responsibility as well as feedback on tasks that have been carried out.

Job characteristic models are an approach to job enrichment. Job enrichment programs seek to design jobs in a way that helps incumbents satisfy their needs for growth, recognition, and responsibility. Job enrichment adds a source of satisfaction to work. This method increases responsibility, autonomy, and control (Simamora, 2012).

According to Gitosudarmo (2010), job characteristics are the implementation of employee duties which include authority, responsibility and tasks that must be done, and can also increase the satisfaction that individuals get from the characteristics of the work concerned. Job characteristics are the basis for employee productivity and job satisfaction which are designed to play an important role in the success and survival of the company.

In Hackman and Oldham's job characteristics model in Robbins and Judge (2015) there are five core characteristics that influence critical psychological states, namely skill diversity, task identity, task importance, autonomy and job feedback. The five dimensions of the work characteristics create a person's level of psychological reaction about the meaning, responsibility and knowledge resulting from the job which in turn has an impact on employee motivation, performance and job satisfaction as well as the level of absenteeism and the level of employee turnover. Job s Characteristics have been examined extensively by previous researchers including: (Harini et al., 2020), (Masydzulhak et al., 2016), and (Silitonga et al., 2017)

\section{Compensation}

Rivai and Sagala (2011) suggest that compensation is something that employees receive as a substitute for their service contribution to the company. The provision of compensation is one of the functions of HRM which is related to all types of individual awards as an exchange for carrying out organizational tasks. Singodimedjo in Sutrisno (2012) states that compensation is all 
remuneration received by an employee from his company as a result of the service / labor he has provided to the company. Meanwhile, according to Simamora (2012), compensation is all forms of financial returns, services and benefits received by employees as part of the employment relationship.

According to Notoatmodjo in Sutrisno (2012), there are several objectives of compensation that need to be considered, namely: 1) Respecting work performance, providing adequate compensation is an organizational reward for employee work performance. Furthermore, it will encourage employee behaviors or performance as desired by the company, for example high productivity; 2) Ensuring fairness, with a good compensation system will ensure justice among employees in the organization. Each employee will receive compensation in accordance with their duties, functions, positions and work performance; 3) Retaining employees, with a good compensation system, employees will be more survival working in the organization. This means preventing employees from leaving the organization in search of more profitable jobs; 4) Obtaining quality employees. With a good compensation system, it will attract more prospective employees and also have more opportunities to choose the best employees; 5) Control costs. With a good compensation system, it will reduce the frequency of recruitment, as a result of the more frequent employees who leave looking for more profitable jobs in other places. This translates to cost savings for the recruitment and selection of prospective new employees; 6) Compliance with regulations. A good compensation system is a demand from the government. A good company is required to have a good compensation administration system.

According to Rivai and Sagala (2011) based on the type of compensation, compensation is grouped into two groups, namely financial compensation and non-financial compensation. Furthermore, financial compensation consists of direct compensation and indirect compensation. Direct compensation consists of direct payments to employees in the form of wages, salaries, bonuses or commissions. Meanwhile, indirect compensation consists of all payments that are not covered by direct financial compensation which includes holidays, various kinds of insurance, services such as child care or religious care and so on. Meanwhile, non-financial compensation can be in the form of praise, appreciation and recognition that affect employee motivation, productivity and satisfaction.

Compensation have been examined extensively by previous researchers including:(Riyanto, Pratomo, et al., 2017), dan (Purba et al., 2017),

\section{Job satisfaction}

Everyone who works expects to get the satisfaction of his place of work. Basically, job satisfaction is an individual thing because each individual will have a different level of satisfaction according to the values that apply in each individual. The more aspects of work that are in accordance with individual desires, the higher the level of perceived satisfaction.

Job satisfaction is a pleasant emotional attitude and loves his job. This attitude is reflected by work morale, discipline and work performance. Job satisfaction is enjoyed at work, outside work, and a combination of inside and outside work (Hasibuan, 2012). According to Robbins and Judge (2015) job satisfaction is a general attitude towards a person's job, the difference between the amount of reward an employee receives and the amount they believe they should receive.

In addition, Rivai and Sagala (2011) define job satisfaction as an evaluation that describes a person who feels happy or unhappy, satisfied or dissatisfied at work. Furthermore, Handoko (2011) argues that job satisfaction is a pleasant or unpleasant emotional state in which employees view 
their work. Job satisfaction reflects a person's feelings about his job. Job satisfaction is related to an assessment of job characteristics, environment, and emotional experiences at work. Satisfied employees have good ratings of their work, based on their observations and experiences. Job satisfaction is a set of attitudes about different aspects of a job and job context.

Job satisfaction will encourage employees to perform better. Better performance will lead to higher economic and psychological rewards. If the benefits are deemed appropriate and fair, there will be greater satisfaction because employees feel that they are receiving rewards according to their performance. Conversely, if the rewards are deemed not in accordance with the level of achievement, uncertainty tends to arise. Job satisfaction depends on the suitability or balance between what is expected and reality.

According to Robbins and Judge (2015) the factors that determine job satisfaction are: 1) Mentally challenging work. Employees tend to prefer jobs that give them the opportunity to advance using their skills and abilities. A less challenging job creates boredom, but challenging it too much creates frustration and feelings of failure; 2) Fair remuneration. Every employee wants a wage system and professional policies that are fair and in accordance with their expectations; 3 ) Supporting working conditions, employees care about the work environment both for personal comfort and to make it easier to do good tasks; 4) Supporting colleagues, having friendly and supportive colleagues can lead to increased job satisfaction; and 5) Conformity between job personalities. People have the same personality type as the job they choose. Thus, will create increased job satisfaction. Job satisfaction have been examined extensively by previous researchers including: (Harini et al., 2020), (Masydzulhak et al., 2016), and (Silitonga et al., 2017)

\section{RESEARCH METHODS}

This type of research is library research, which is a series of studies relating to the method of collecting library data, or research where the object of research is extracted through a variety of library information (books, encyclopedias, scientific journals, newspapers, magazines, and documents) (Arikunto, 2012). Literature research or literature research (literature review, literature research) is research that critically reviews or reviews the knowledge, ideas, or findings contained in the academic-oriented literature, and formulates theoretical and methodological contributions to certain topics. (Sugiyono, 2012). The focus of library research is to find various theories, laws, propositions, principles, or ideas that are used to analyze and solve the research questions formulated. The nature of this research is qualitative analysis.

In qualitative research, literature review should be used consistently with methodological assumptions. This means that it must be used inductively so that it does not lead to the questions posed by the researcher. One of the main reasons for conducting qualitative research is that it is exploratory (Hapzi Ali. Nandan Limakrisna, 2013).

Furthermore, it is discussed in depth in the section entitled "Related Literature" or literature review ("Review of Literature"), as a basis for the formulation of hypotheses and will then become the basis for making comparisons with the results or findings revealed in the research. (Hapzi Ali. Nandan Limakrisna, 2013).

\section{FINDINGS AND DISCUSSION}

\section{Result}


This article analyzes and discusses the variables of Human Resource Management (HRM), namely: Organizational Commitment, Job Characteristics, Compensation, and Job Satisfaction. Where Job Characteristics, Compensation, and Job Satisfaction affect Organizational Commitment, Research and previous articles relevant to this article include:

\section{Job Characteristics and Job Satisfaction}

There have been many studies and published articles on job characteristics and job satisfaction by previous researchers. Job Characteristics articles include: (Lok \& Crawford, 2004); (Katsikea et al., 2011); (Ozturk et al., 2014); (Kónya et al., 2016); (Gillet \& Vandenberghe, 2014); (Birtch et al., 2016) and (Santos et al., 2016). Job satisfaction articles include: (Nguyen et al., 2020); (Rhoades \& Eisenberger, 2002); (Abidin et al., 2016); (Harini et al., 2020); (Zahra, 2015); (Lok \& Crawford, 2004); (Masydzulhak et al., 2016); (Silitonga et al., 2017); (Carrière \& Bourque, 2009); and (Paksoy et al., 2017).

\section{Compensation and Job Satisfaction}

The research and publication of articles related to compensation and job satisfaction variables by previous researchers. Compensation articles include: (Purnami, 2017); (Riyanto et al., 2017); (Purba et al., 2017); (Gunarto et al., 2020); (Muhammad \& Abdullah, 2016); and (Nguyen et al., 2020). Job Satisfaction articles include: (Nguyen et al., 2020); (Rhoades \& Eisenberger, 2002); (Abidin et al., 2016); (Harini et al., 2020); (Zahra, 2015); (Lok \& Crawford, 2004); (Masydzulhak et al., 2016); (Silitonga et al., 2017); (Carrière \& Bourque, 2009); and (Paksoy et al., 2017).

\section{Job Characteristics and Organizational Commitment}

There have been many studies and published articles on job characteristics and organizational commitment by previous researchers. Job Characteristics articles include: (Lok \& Crawford, 2004); (Katsikea et al., 2011); (Ozturk et al., 2014); (Kónya et al., 2016); (Gillet \& Vandenberghe, 2014); (Birtch et al., 2016) and (Santos et al., 2016). Organizational Commitment articles include: (Purnami, 2017); (Setiadi et al., 2016); (Abidin et al., 2016); (Harini et al., 2020); and (Limakrisna et al., 2016).

\section{Compensation and Organizational Commitment}

The research and publication of articles related to compensation variables and Organizational Commitment by previous researchers. Compensation articles include: (Purnami, 2017); (Riyanto et al., 2017); (Purba et al., 2017); (Gunarto et al., 2020); (Muhammad \& Abdullah, 2016); dan (Nguyen et al., 2020). Organizational Commitment articles include: (Syahrian, 2020); (Keskes, 2014); (Lok \& Crawford, 2004); (DeviMageshkumar, 2016); and (Prayetno \& Ali, 2017).

\section{Job Satisfaction and Organizational Commitment}

Then for research and publication of articles related to job satisfaction variables and Organizational Commitment by previous researchers. Job Satisfaction articles include: (Nguyen et al., 2020); (Rhoades \& Eisenberger, 2002); (Abidin et al., 2016); (Harini et al., 2020); (Zahra, 2015); (Lok \& Crawford, 2004); (Masydzulhak et al., 2016); (Silitonga et al., 2017); (Carrière \& Bourque, 2009); and (Paksoy et al., 2017). Organizational Commitment articles include: (Khan et al., 2016); (Masydzulhak et al., 2016); (Silitonga et al., 2017); (Islam et al., 2015); and (Nazir \& Islam, 2017). 


\section{Conceptual Framework}

Based on the theoretical study and the relationship between variables, the model or Conceptual Framework of this article in order to construct a hypothesis is as follows:

a. The effect of job characteristics on job satisfaction based on research results: (Birtch et al., 2016); (Ozturk et al., 2014); (Ali et al., 2014); (Loher et al., 1985); (Judge, Bono, \& Locke, 2000); and (Judge, Bono, Locke, et al., 2000), (Limakrisna et al., 2016), (Harini et al., 2020), (Prayetno \& Ali, 2017), (Riyanto, Yanti, et al., 2017), and (Masydzulhak et al., 2016).

b. The effect of compensation on job satisfaction based on research results: (Mabaso \& Dlamini, 2017); (Salisu et al., 2015); (Adeoye \& Fields, 2014); (Yaseen, 2013); Pebrianti dkk (2012), Mardahleni (2013), Sinollah (2011) and Humairoh dkk (2015), (Harini et al., 2020), (Masydzulhak et al., 2016), and (Silitonga et al., 2017)

c. The effect of job characteristics on organizational commitment based on research results (Katsikea et al., 2011); (Ozturk et al., 2014); (Kónya et al., 2016); (Gillet \& Vandenberghe, 2014); Pratiwi, Mayasari, dan Shalihatulhayah (2013), Tamalero, Swasto, dan Hamid, (2012), and Handaru, Abdillah, Waspodo (2013), Job satisfaction have been examined extensively by previous researchers including: (Harini et al., 2020), (Masydzulhak et al., 2016), and (Silitonga et al., 2017)

d. The effect of compensation on organizational commitment based on research results: (Muhammad \& Abdullah, 2016); (Dhurup et al., 2016); Pratama, E.W., Musadieq, M.A., dan Mayowan, Y (2016); Rizal, M., Idrus, M.S., Djumahir., \& Mintarti. R (2014); Nawab, S., \& Bhatti, K.K (2011); Wadhawan, C., Mishra, M., \& Garg, K (2017); and Riana, I.G \& Wirasedana, I.W.P (2016), Compensation have been examined extensively by previous researchers including:(Riyanto, Pratomo, et al., 2017), dan (Purba et al., 2017),

e. The effect of job satisfaction on organizational commitment based on research results: (Abidin et al., 2016); (Harini et al., 2020); (Masydzulhak et al., 2016); (Carrière \& Bourque, 2009); (Ozturk et al., 2014); (Birtch et al., 2016); Tamalero, Y, Swasto, B., Hamid, D (2012), Pratama, E.W., Musadieq, M.A., dan Mayowan, Y (2016), and Novieka and Prasetya, A (2018).

From the formulation of the problem of writing this article and reviewing literature studies from both relevant books and articles, the frame for this article is processed as below.

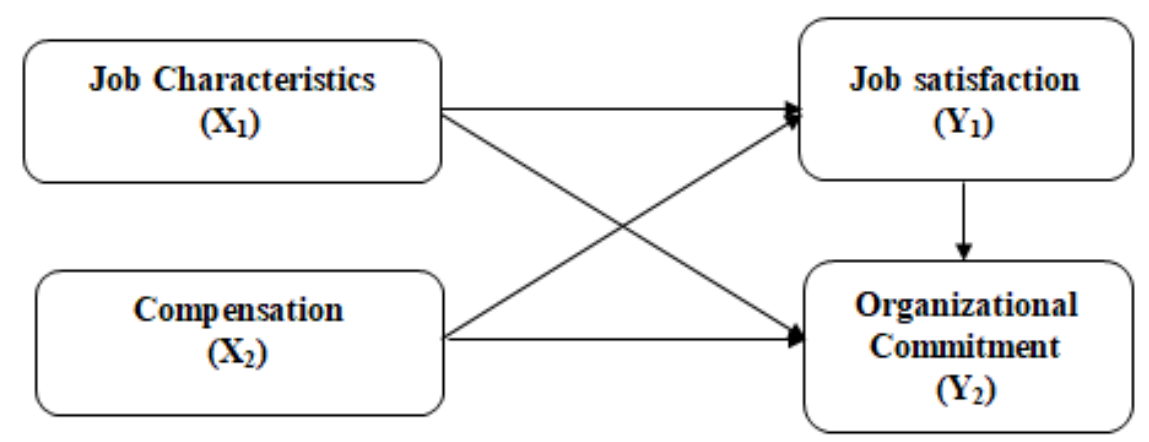

Figure 1. Conceptual Framework 


\section{Discussion}

\section{Relationship between Job Characteristics and Job Satisfaction}

Job characteristics are the implementation of employee duties which include the authority, responsibilities and tasks that must be performed, and can also increase the satisfaction that individuals get from the characteristics of the work concerned. Job characteristics are the basis for employee productivity and job satisfaction which are designed to play an important role in the success and survival of the company (Gitosudarmo, 2010).

William and Hazer (1986) say that job satisfaction is the effective orientation of individual workers towards their work and its characteristics. Job characteristics are the main factors found consistently in the formation of job satisfaction. Studies on the importance of different job characteristics find consistently that the nature of the job itself is a major determinant of job satisfaction (Wexley and Yukl, 2003), (Harini et al., 2020), (Masydzulhak et al., 2016), and (Silitonga et al., 2017)

Various studies have proven that if in work someone has the autonomy to act, there are variations, make an important contribution to organizational success and employees get feedback about the results of the work they do, they will feel satisfied. (Birtch et al., 2016); (Ozturk et al., 2014); (Ali et al., 2014); (Loher et al., 1985); (Judge, Bono, \& Locke, 2000); and (Judge, Bono, Locke, et al., 2000).

The greater the variety of activities carried out by a worker, the less tedious the job is. Jobs that are very tedious are those with the same activities, simple and repetitive every few minutes, or hundreds of times every day. A job that includes more skills and talents that are relevant to the identity of the worker, the more workers feel that they are doing meaningful work rather than just being on time (Wexley and Yukl, 2003). Furthermore, Robins and Judge (2015) say that a job that has autonomy will give the office holder a feeling of personal responsibility for the results and if a job provides feedback, the employee will know how effective he is working.

\section{Compensation Relationship with Job Satisfaction}

Compensation as an important function in human resource management. Serves as a means of pulling, maintaining and maintaining workforce for the benefit of the organization (Martoyo, in Sinollah, 2011). Furthermore, Martoyo in Sinollah (2011) states that compensation is a form of appreciation for the services of a person at the company where he works. The realization of this remuneration requires a regulatory mechanism that has a logical, rational and strong basis. When compensation is given correctly, employees will be satisfied and motivated to achieve organizational goals.

Many studies suggest that compensation has a large influence and impact on employee job satisfaction at work, among others, research conducted by (Mabaso \& Dlamini, 2017); (Salisu et al., 2015); (Adeoye \& Fields, 2014); (Yaseen, 2013); Pebrianti dkk (2012), Mardahleni (2013), Sinollah (2011) and Humairoh (2015), (Riyanto, Pratomo, et al., 2017), dan (Purba et al., 2017), which revealed that compensation consisting of financial compensation and non-financial compensation has a positive and significant effect on employee job satisfaction.

In addition, this statement is also supported by the opinion of experts, including Sutrisno (2012), which states that financial factors are factors related to job satisfaction. Because this factor provides guarantees and employee welfare, which includes the system and the amount of salary, social security, various benefits, facilities provided, promotions and so on.

In addition, Handoko in Sinollah (2011) states that one of the factors that allows the growth of job satisfaction is proper and fair arrangement of compensation to employees. If the value of 
remuneration or compensation provided by the company is in accordance with the expectations of the employees, it can be said that the employees have experienced job satisfaction.

\section{Relationship between Job Characteristics and Organizational Commitment}

Job characteristics are basically related to the design of a work system for employees or known as job characteristics. Monotonous jobs or routinely using only the type of expertise, for example, can bore employees with their work compared to employees who work using a variety of jobs. Job characteristics are an attempt to identify the task characteristics of a job, how these characteristics are combined to form different jobs with their relationship to motivation, job satisfaction, organizational commitment and employee performance.

A study by Udo et al conducted on manufacturing plant managers in the USA, illustrates that the turnover intentions among factory managers are the result of a complex relationship between role stressors, job characteristics, job involvement, job satisfaction and organizational commitment (Tamalero, Swasto, and Hamid, 2012). Elanain further stated in Tamalero, Swasto, and Hamid (2012) which emphasized that to increase employee commitment and to reduce turnover intentions, companies need to pay attention to job characteristics factors.

Several previous studies have also revealed that job characteristics have an influence on employee organizational commitment. Among them are research conducted by (Katsikea et al., 2011); (Ozturk et al., 2014); (Kónya et al., 2016); (Gillet \& Vandenberghe, 2014); Pratiwi, Mayasari, and Shalihatulhayah (2013), Tamalero, Swasto, and Hamid, (2012), and Handaru, Abdillah, Waspodo (2013), (Harini et al., 2020), (Masydzulhak et al., 2016), and (Silitonga et al., 2017)

where the results of their research suggest that job characteristics have a significant effect on organizational commitment.

\section{Compensation Relationship With Organizational Commitment}

Compensation is a reply from the company that must be received by employees, both financial and non-financial. The purpose of providing compensation itself according to Hasibuan (2012) is a bond of cooperation, job satisfaction, effective procurement, motivation, employee stability, discipline, and commitment to work.

The amount of compensation received with work targets and workloads that are completed will further motivate employees to work seriously in achieving the goals and objectives of the organization (Pratama, E.W., Musadieq, M.A., and Mayowan, Y., 2016). Providing good compensation will motivate employees to commit to an organization that has met their daily needs (Garay in Pratama, E.W., Musadieq, M.A., and Mayowan, Y., 2016), (Riyanto, Pratomo, et al., 2017), dan (Purba et al., 2017),

Several previous studies have also revealed that compensation affects organizational commitment, including research conducted by Rizal, M., Idrus, M.S., Djumahir., \& Mintarti. R (2014) who argues that direct compensation can strengthen organizational commitment. other than that (Muhammad \& Abdullah, 2016); (Dhurup et al., 2016); Pratama, E.W., Musadieq, M.A., and Mayowan, Y (2016); Rizal, M., Idrus, M.S., Djumahir., \& Mintarti. R (2014); Nawab, S., \& Bhatti, K.K (2011); Wadhawan, C., Mishra, M., \& Garg, K (2017); and Riana, I.G \& Wirasedana, I.W.P (2016) in their research also suggest that compensation positively and significantly has a strong influence on organizational commitment.

\section{Relationship between Job Satisfaction and Organizational Commitment}


Job satisfaction is a form of a person's feelings about his job, work situation and relationships with colleagues. Therefore, job satisfaction is something that is important for an employee to have, in interacting with his work environment so that the responsibilities given by the company can be carried out properly in accordance with company goals. Job satisfaction is considered important in the scope of the organization because it has a big influence on organizational commitment, this was stated by Mathis \& Jackson (2006) which states that people who are relatively satisfied with their work will be more committed to the organization and people who are committed to the organization are more likely get greater satisfaction.

Job satisfaction has a positive and strong influence on organizational commitment. People who get a higher level of job satisfaction tend to feel that the level of affective commitment and normative commitment is higher. Meanwhile, the effect on continuance commitment is weaker. Affective commitment is a commitment that arises because of emotional closeness to the organization, self-identification and active involvement in the organization. Continuance commitment is based on workers' perceptions of the losses they will incur if they leave the organization. Meanwhile, normative commitment is related to workers' feelings about having to stay in the organization (Wibowo, 2014).

Several previous studies have also revealed that job satisfaction has a positive and significant effect on organizational commitment, including research conducted by: (Abidin et al., 2016); (Harini et al., 2020); (Masydzulhak et al., 2016); (Carrière \& Bourque, 2009); (Ozturk et al., 2014); (Birtch et al., 2016); Tamalero, Y, Swasto, B., Hamid, D (2012), Pratama, E.W., Musadieq, M.A., and Mayowan, Y (2016), and Novieka and Prasetya, A (2018). where the results of his research suggest that job satisfaction has a significant effect on organizational commitment.

Apart from Job Characteristics and Compensation which affect Job Satisfaction and Organizational Commitment, there are many other factors including:

1) Leadership: (Limakrisna et al., 2016), (Bastari et al., 2020), (Anwar et al., 2020), (Ali, Mukhtar, et al., 2016), (Djoko Setyo Widodo, P. Eddy Sanusi Silitonga, 2017), (Chauhan et al., 2019), (Elmi et al., 2016).

2) Work Motivation: (Riyanto, Sutrisno, et al., 2017a), (Bastari et al., 2020), (Prayetno \& Ali, 2017), (Rivai et al., 2017), (Chauhan et al., 2019), (Aima et al., 2017), and (Masydzulhak et al., 2016).

3) Creativity: (Desfiandi, Fionita, et al., 2017), (Yacob et al., 2020), (Richardo et al., 2020), (Christina Catur Widayati et al., 2020), (Prayetno \& Ali, 2020b), (C.C. Widayati et al., 2020).

4) Knowledge: (Desfiandi, Fionita, et al., 2017), (Prayetno \& Ali, 2020a), (Mukhtar et al., 2016), (Brata, Husani, Hapzi, 2017), (Toto Handiman \& Ali, 2019), and (Prayetno \& Ali, 2020b).

\section{CONCLUSION AND RECOMMENDATION}

Based on the formulation of the articles, the results and discussions that are reviewed and discussed in this article, it can be concluded that to build a hypothesis for further research are: a) There is an effect of job characteristics on job satisfaction; a) There is a compensation effect on job satisfaction; c) There is an effect of job characteristics on organizational commitment; d) There is a compensation effect on organizational commitment; and e) There is an effect of job satisfaction on organizational commitment.

Based on the conclusions above, the suggestion in this article is that there are many other factors that affect employee organizational commitment at all types and levels of the 
organization, therefore further study is needed to complement what other factors can influence organization commitment.

\section{BIBLIOGRAPHY}

Abidin, M. I. Z., Pangtuluran, Y., \& Maria, S. (2016). Pengaruh Kepuasan Kerja, Lingkungan Kerja Dan Efikasi Diri Terhdap Komitmen Organisasi Di Rumah Sakit Smc Samarinda. Jurnal Ekonomi Dan Keuangan.

Adeoye, A. O., \& Fields, Z. (2014). Compensation Management and Employee Job Satisfaction: A Case of Nigeria. Journal of Social Sciences. https://doi.org/10.1080/09718923.2014.11893369

Ali, S. A. M., Said, N. A., Yunus, N. M., Kader, S. F. A., Latif, D. S. A., \& Munap, R. (2014). Hackman and Oldham's Job Characteristics Model to Job Satisfaction. Procedia - Social and Behavioral Sciences. https://doi.org/10.1016/j.sbspro.2014.03.646

Aima, P. H., Adam, R., \& Ali, P. H. (2017). Model of Employee Performance: Competence Analysis and Motivation (Case Study at PT. Bank Bukopin, Tbk Center). Journal of Research in Business and Management.

Ali, H., Mukhtar, \& Sofwan. (2016). Work ethos and effectiveness of management transformative leadership boarding school in the Jambi Province. International Journal of Applied Business and Economic Research.

Anwar, K., Muspawi, M., Sakdiyah, S. I., \& Ali, H. (2020). The effect of principal's leadership style on teachers' discipline. Talent Development and Excellence.

Bastari, A., -, H., \& Ali, H. (2020). DETERMINANT SERVICE PERFORMANCE THROUGH MOTIVATION ANALYSIS AND TRANSFORMATIONAL LEADERSHIP. International Journal of Psychosocial Rehabilitation. https://doi.org/10.37200/ijpr/v24i4/pr201108

Brata, Husani, Hapzi, B. H. S. A. (2017). Saudi Journal of Business and Management Studies Competitive Intelligence and Knowledge Management: An Analysis of the Literature. Saudi Journal of Business and Management Studies. https://doi.org/10.21276/sjbms

Birtch, T. A., Chiang, F. F. T., \& Van Esch, E. (2016). A social exchange theory framework for understanding the job characteristics-job outcomes relationship: the mediating role of psychological contract fulfillment. International Journal of Human Resource Management. https://doi.org/10.1080/09585192.2015.1069752

Carrière, J., \& Bourque, C. (2009). The effects of organizational communication on job satisfaction and organizational commitment in a land ambulance service and the mediating role of communication satisfaction. Career Development International. https://doi.org/10.1108/13620430910933565

Chauhan, R., Ali, H., \& Munawar, N. A. (2019). BUILDING PERFORMANCE SERVICE THROUGH TRANSFORMATIONAL LEADERSHIP ANALYSIS, WORK STRESS AND WORK MOTIVATION (EMPIRICAL CASE STUDY IN STATIONERY DISTRIBUTOR COMPANIES). Dinasti International Journal of Education Management And Social Science. https://doi.org/10.31933/dijemss.v1i1.42

Desfiandi, A., Fionita, I., \& Ali, H. (2017). Implementation of the information systems and the creative economy for the competitive advantages on tourism in the province of Lampung. International Journal of Economic Research.

Djoko Setyo Widodo, P. Eddy Sanusi Silitonga, \& H. A. (2017). Organizational Performance: Analysis of Transformational Leadership Style and Organizational Learning. Saudi Journal of Humanities and Social Sciences. https://doi.org/10.21276/sjhss.2017.2.3.9

DeviMageshkumar, S. (2016). Influence of Perceived Organizational Support, Organizational 
Commitment on Organizational Citizenship Behavior among Marketing Executives. The International Journal of Indian Psychology.

Dhurup, M., Surujlal, J., \& Kabongo, D. M. (2016). Finding Synergic Relationships in Teamwork, Organizational Commitment and Job Satisfaction: A Case Study of a Construction Organization in a Developing Country. Procedia Economics and Finance. https://doi.org/10.1016/s2212-5671(16)00060-5

Elmi, F., Setyadi, A., Regiana, L., \& Ali, H. (2016). Effect of leadership style, organizational culture and emotional intelligence to learning organization: On the Human Resources Development Agency of Law and Human Rights, Ministry of Law and Human Rights. International Journal of Economic Research.

Gillet, N., \& Vandenberghe, C. (2014). Transformational leadership and organizational commitment: The mediating role of job characteristics. Human Resource Development Quarterly. https://doi.org/10.1002/hrdq.21192

Gunarto, M., Yunilda, \& Yessy Widiastuty. (2020). THE EFFECT OF COMPENSATION AND COMMITMENT TO EMPLOYEE MOTIVATION IN A SUB-DISTRICT PALEMBANG. Dinasti International Journal of Management Science. https://doi.org/10.31933/dijms.v1i5.276

Hapzi Ali. Nandan Limakrisna. (2013). Metodologi Penelitian ( Petunjuk Praktis Untuk Pemecahan Masalah Bisnis, Penyusunan Skripsi, Tesis, dan Disertasi. In Deeppublish: Yogyakarta.

Harini, S., Hamidah, Luddin, M. R., \& Ali, H. (2020). Analysis supply chain management factors of lecturer's turnover phenomenon. International Journal of Supply Chain Management.

Islam, T., Ahmed, I., \& Ahmad, U. N. B. U. (2015). The influence of organizational learning culture and perceived organizational support on employees' affective commitment and turnover intention. Nankai Business Review International. https://doi.org/10.1108/NBRI-012015-0002

Judge, T. A., Bono, J. E., \& Locke, E. A. (2000). Personality and job satisfaction: The mediating role of job characteristics. Journal of Applied Psychology. https://doi.org/10.1037//00219010.85.2.237

Judge, T. A., Bono, J. E., Locke, E. A., Tippie, H. B., \& Judge, T. A. (2000). Personality and job satisfaction: The mediating role of job characteristics. Journal of Applied Psychology. https://doi.org/10.1037/0021-9010.85.2.237

Katsikea, E., Theodosiou, M., Perdikis, N., \& Kehagias, J. (2011). The effects of organizational structure and job characteristics on export sales managers' job satisfaction and organizational commitment. Journal of World Business. https://doi.org/10.1016/j.jwb.2010.11.003

Keskes, I. (2014). Relationship between leadership styles and dimensions of employee organizational commitment: A critical review and discussion of future directions. Intangible Capital. https://doi.org/10.3926/ic.476

Khan, M. L., Salleh, R., \& Hemdi, M. A. Bin. (2016). Effect of protean career attitudes on organizational commitment of employees with moderating role of organizational career management. International Review of Management and Marketing.

Kónya, V., Matić, D., \& Pavlović, J. (2016). The influence of demographics, job characteristics and characteristics of organizations on employee commitment. Acta Polytechnica Hungarica.

Limakrisna, N., Noor, Z. Z., \& Ali, H. (2016). Model of employee performance: The empirical 
study at civil servants in government of west java province. International Journal of Economic Research.

Loher, B. T., Noe, R. A., Moeller, N. L., \& Fitzgerald, M. P. (1985). A Meta-Analysis of the Relation of Job Characteristics to Job Satisfaction. Journal of Applied Psychology. https://doi.org/10.1037/0021-9010.70.2.280

Lok, P., \& Crawford, J. (2004). The effect of organisational culture and leadership style on job satisfaction and organisational commitment: A cross-national comparison. Journal of Management Development. https://doi.org/10.1108/02621710410529785

Mukhtar, Risnita, Saifillah, M. S., \& Ali, H. (2016). Effect of knowledge management and work commitment to employees satisfaction services (Study on teacher Madrasah Aliyah Country Jambi Province). International Journal of Economic Research.

Mabaso, C. M., \& Dlamini, B. I. (2017). Impact of Compensation and Benefits on Job Satisfaction. Research Journal of Business Management. https://doi.org/10.3923/rjbm.2017.80.90

Masydzulhak, P. D., Ali, P. D. H., \& Anggraeni, L. D. (2016). The Influence of work Motivationand Job Satisfaction on Employee Performance and Organizational Commitment Satisfaction as an Intervening Variable in PT. Asian Isuzu Casting Center. In Journal of Research in Business and Management.

Muhammad, I. G., \& Abdullah, H. H. (2016). Assessment of organizational performance: Linking the motivational antecedents of empowerment, compensation and organizational commitment. International Review of Management and Marketing.

Nazir, O., \& Islam, J. U. (2017). Enhancing organizational commitment and employee performance through employee engagement: An empirical check. South Asian Journal of Business Studies. https://doi.org/10.1108/SAJBS-04-2016-0036

Nguyen, P. T., Yandi, A., \& Mahaputra, M. R. (2020). FACTORS THAT INFLUENCE EMPLOYEE PERFORMANCE: MOTIVATION, LEADERSHIP, ENVIRONMENT, CULTURE ORGANIZATION, WORK ACHIEVEMENT, COMPETENCE AND COMPENSATION (A STUDY OF HUMAN RESOURCE MANAGEMENT LITERATURE STUDIES). Dinasti International Journal of Digital Business Management.

Ozturk, A. B., Hancer, M., \& Im, J. Y. (2014). Job Characteristics, Job Satisfaction, and Organizational Commitment for Hotel Workers in Turkey. Journal of Hospitality Marketing and Management. https://doi.org/10.1080/19368623.2013.796866

Paksoy, M., Soyer, F., \& Çalık, F. (2017). The impact of managerial communication skills on the levels of job satisfaction and job commitment. Journal of Human Sciences. https://doi.org/10.14687/jhs.v14i1.4259

Prayetno, S., \& Ali, H. (2017). Analysis of advocates organizational commitment and advocates work motivation to advocates performance and its impact on performance advocates office. International Journal of Economic Research.

Purba, C. B., Arzio, \& Ali, H. (2017). The influence of compensation, working environment and organization culture on working productivity of BPJS (workers social security agency) employment staff in Rawamangun Branch. Man in India.

Purnami, P. R. (2017). Pengaruh Kompensasi Dan Persepsi Dukungan Organisasi Terhadap Komitmen Organisasi Dan Kinerja Karyawanrumah Sakit Balimed Karangasem. Jurnal Ekonomi \& Bisnis. https://doi.org/10.22225/JJ.4.1.226.95-107

Prayetno, S., \& Ali, H. (2017). Analysis of advocates organizational commitment and advocates work motivation to advocates performance and its impact on performance advocates office. 
International Journal of Economic Research.

Prayetno, S., \& Ali, H. (2020a). Entrepreneurial supply chain management competence: Predictors of work motivation advocate. International Journal of Supply Chain Management.

Prayetno, S., \& Ali, H. (2020b). The influence of work motivation, entrepreneurship knowledge and advocate independence on advocate performance. International Journal of Innovation, Creativity and Change.

Purba, C. B., Arzio, \& Ali, H. (2017). The influence of compensation, working environment and organization culture on working productivity of BPJS (workers social security agency) employment staff in Rawamangun Branch. Man in India.

Rhoades, L., \& Eisenberger, R. (2002). Perceived organizational support: A review of the literature. Journal of Applied Psychology. https://doi.org/10.1037/0021-9010.87.4.698

Riyanto, S., Pratomo, A., \& Ali, H. (2017). EFFECT OF COMPENSATION AND JOB INSECURITY ON EMPLOYEE ENGAGEMENT (STUDY ON EMPLOYEE OF BUSINESS COMPETITION SUPERVISORY COMMISSION SECRETARIAT). International Journal of Advanced Research. https://doi.org/10.21474/ijar01/4139

Richardo, Hussin, M., Bin Norman, M. H., \& Ali, H. (2020). A student loyalty model: Promotion, products, and registration decision analysis-Case study of griya english fun learning at the tutoring institute in wonosobo central Java. International Journal of Innovation, Creativity and Change.

Rivai, A., Suharto, \& Ali, H. (2017). Organizational performance analysis: Loyalty predictors are mediated by work motivation at urban village in Bekasi City. International Journal of Economic Research.

Riyanto, S., Pratomo, A., \& Ali, H. (2017). EFFECT OF COMPENSATION AND JOB INSECURITY ON EMPLOYEE ENGAGEMENT (STUDY ON EMPLOYEE OF BUSINESS COMPETITION SUPERVISORY COMMISSION SECRETARIAT). International Journal of Advanced Research. https://doi.org/10.21474/ijar01/4139

Riyanto, S., Sutrisno, A., \& Ali, H. (2017). International Review of Management and Marketing The Impact of Working Motivation and Working Environment on Employees Performance in Indonesia Stock Exchange. International Review of Management and Marketing.

Riyanto, S., Yanti, R. R., \& Ali, H. (2017). The Effect of Training and Organizational Commitment on Performance of State University of Jakarta Student Cooperative (KOPMA UNJ) Management. Saudi Journal of Humanities and Social Sciences. https://doi.org/10.21276/sjhss

Salisu, J. B., Chinyio, E., \& Suresh, S. (2015). The impact of compensation on the job satisfaction of public sector construction workers of jigawa state of Nigeria. The Business and Management Review.

Santos, A., Chambel, M. J., \& Castanheira, F. (2016). Relational job characteristics and nurses' affective organizational commitment: The mediating role of work engagement. Journal of Advanced Nursing. https://doi.org/10.1111/jan.12834

Setiadi, A., Winarti, E., \& Taufiq. (2016). Analisis Komunikasi Dan Kompetensi Terhadap Komitmen Organisasi Dengan Pengembangan Karir Sebagai Vaiabel Moderasi (Studi Kasus Pada Akademi Kepolisian). Dharma Ekonomi.

Silitonga, P. E. S., Widodo, D. S., \& Ali, H. (2017). Analysis of the effect of organizational commitment on organizational performance in mediation of job satisfaction (Study on Bekasi City Government). International Journal of Economic Research.

Syahrian. (2020). THE ROLE OF LEADERSHIP, ORGANIZATIONAL COMMITMENT AND 
COMPETENCE IN THE ORGANIZATIONAL CULTURE OF THE STATE CIVIL APPARATUS AND ITS IMPLICATIONS FOR THE PERFORMANCE OF PUBLIC SERVICES IN THE TRADE AND INDUSTRY OFFICES OF REGENCIES. Dinasti International Journal of Management Science. https://doi.org/10.31933/dijms.v1i3.75

Toto Handiman, U., \& Ali, H. (2019). The Influence of Brand Knowledge and Brand Relationship On Purchase Decision Through Brand Attachment. In International Journal of Business Marketing and Management (IJBMM).

Widayati, C.C., Ali, H., Permana, D., \& Nugroho, A. (2020). The role of destination image on visiting decisions through word of mouth in urban tourism in Yogyakarta. International Journal of Innovation, Creativity and Change, 12(3).

Widayati, Christina Catur, Ali, H., Permana, D., \& Nugroho, A. (2020). The role of destination image on visiting decisions through word of mouth in urban tourism in Yogyakarta. International Journal of Innovation, Creativity and Change.

Yacob, S., Sucherly, Sari, D., Mulyana, A., \& Ali, H. (2020). An Optimising strategy for minimarket modern retail business performance in Indonesia. International Journal of Innovation, Creativity and Change.

Yaseen, A. (2013). Effect of Compensation Factors on Employee Satisfaction- A Study of Doctor's Dissatisfaction in Punjab. International Journal of Human Resource Studies. https://doi.org/10.5296/ijhrs.v3i1.3351

Zahra, N. (2015). PENGARUH GAYA KEPEMIMPINAN TERHADAP KOMITMEN ORGANISASI MELALUI ASPEK KEPUASAN KERJA KARYAWAN DAN KEPERCAYAAN PADA SEKTOR PERBANKAN. Jurnal Manajemen Dan Pemasaran Jasa. https://doi.org/10.25105/jmpj.v8i1.1406 